Global Solidarity 



\title{
Global Solidarity
}

\author{
Lawrence Wilde
}

EDINBURGH

University Press 
For Joan Catherine and Frances Catherine

(C) Lawrence Wilde, 2013

Edinburgh University Press Ltd

22 George Square, Edinburgh

www.euppublishing.com

Typeset in 11/14 Sabon by

Servis Filmsetting Ltd, Stockport, Cheshire, and printed and bound in Great Britain by

CPI Group (UK) Ltd, Croydon CR0 4YY

A CIP record for this book is available from the British Library

ISBN 9780748640294 (hardback)

ISBN 9780748640287 (paperback)

ISBN 9780748674541 (webready PDF)

ISBN 9780748674565 (epub)

ISBN 9780748674558 (Amazon ebook)

The right of Lawrence Wilde to be identified as author of this work has been asserted in accordance with the Copyright, Designs and Patents Act 1988.

Published with the support of the Edinburgh University Scholarly

Publishing Initiatives Fund. 